\title{
FAHR Sendromu: Olgu Sunumu
}

\author{
FAHR Syndrome: Case Report
}

Buket Tuğan Yıldız

' Ankara Üniversitesi Tıp Fakültesi Nöroloji Anabilim Dalı

Fahr sendromu, bilateral ve simetrik olarak bazal gangliyonlar, serebellum ve sentrum semiovaleye kalsiyum ve çeșitli minerallerin birikimi ile ortaya çıkar. En sık görülen klinik prezentasyonu parkinsonizm, kore, tremor, distoni, kognitif bozukluklardır. Bu olgu sadece baș ağrısı șikayetiyle polikliniğe baș vuran, erken dönemde hipokalsemi tedavisi bașlanan bir hasta. Baș ağrısı olan hastalarda etyolojide Fahr sendromu akla gelmeli, özellikle baș ağrısına eșlik eden hipokalsemi semptomları varsa kan kalsiyum düzeyi ve görüntüleme mutlaka istenmelidir.

\section{Anahtar Sözcükler: Fahr Sendromu, Baș Ağrısı, Intrakranial Kalsifikasyon}

Fahr Syndrome revelead accumulation of calcium and various minerals in basal ganglia, cerebellum and centrum semiovale bilaterally and symmetrical. The most common clinical presentations are parkinsonism, chorea, tremor, dystonia, cognitive disorders. This patient is referred to policlinic with complaint of only headache, whose hypocalsemia treatment started early. Fahr Syndrome should be considered in etiology of patient with headache, especially if there are hypocalcemia symptoms accompany to the headache, serum calcium levels and imaging should be wanted.

Key Words: Fahr Syndrome, Headache, Intracranial Calsification

Fahr sendromu, bilateral ve simetrik olarak bazal gangliyonlar, serebellum ve sentrum semiovaleye kalsiyum ve çeşitli minerallerin birikimi ile ortaya ç1kar. Bu sendrom, radyasyon, sistemik hastalıklar, toksinler, hipoparatiroidizm, psödohipoparatiroidizm ve hiperparatiroidizmde sporadik görülebileceği gibi ailesel de olabilir. Fahr sendromu ilk kez 1930 yılinda tanımlanmıştır (1-6). En sık klinik prezentasyonu parkinsonizm ve diğer hiperkinetik hareket bozukluklarıdır (kore, tremor, distoni, atetoz, orofasiyal diskinizi). İkinci en s1k klinik bulgusu kognitif bozukluktur (7-8). Erken tan1 ve tedavinin hayati önemi vardır. Bu olgu, baş ağrısı semptomuyla polikliniğge başvuran bir hasta.

\section{Olgu}

19 yaşında bayan hasta baş ağrısı şikayetiyle nöroloji polikliniğine başvurdu. Hastanın baş ağrısı 10 gündür vardı, bilateral, sıkıştırır tarzdaydı. Mide bulantıs1, kusma, fotofobi, fonofobi eşlik etmiyordu. Ağr1 sürekliydi ve geceleri şiddeti artıyordu. Hasta ağrıdan bağımsız olarak 1 aydır olan ellerinde kasilma tarif ediyordu.

Hastanın nörolojik muayenesi, EEG'si normaldi. Yapilan kan tetkiklerinde kalsiyum 4,8 mg/dl (8,6-10,2), fosfor 7,36 mg/dl (2,7- 4,5), PTH 302,5 $\mathrm{pg} / \mathrm{ml}$ (15-65) idi. Hemogram, diğer biyokimya parametreleri normaldi.

Bilgisayarlı beyin tomografisinde her iki serebellar hemisferde, bazal gangliyonlarda, talamusta ve frontal bölgelerde yaygin kaba kalsifikasyonlar mevcuttu (Şekil 1,2).

Laboratuvar ve radyolojik inceleme sonuçlarına göre hastaya Fahr sendromu tanisi koyuldu. Hipokalsemisi tedavi başland, ancak hasta kontrole gelmedi.

\section{Tartıșma}

Fahr sendromu birçok metabolik bozukluğa özellikle de paratiroid hastalıklarına bağlı olarak ortaya çıkan, bilateral bazal ganglion, dentat nukleus periferal subkortikal beyaz cevherde
Tel: 0 (344) $2282800 / 2691$

Kahramanmaraș Necip Fazıl Şehir Hastanesi Nöroloji Kliniği 
ve serebellumda kalsifikasyonlarla karakterize nadir bir durumdur. Bazal ganglion kalsifikasyonunun etyolojisinde enfeksiyon hastalıklar1 (Brusella, EBV enfeksiyonu, tüberküloz, AIDS), hipertiroidi, hipotiroidi, tuberoskleroz, SLE, motor nöron hastal1ğ1 yer alır. Bu tablodan sorumlu element s1klikla kalsiyumdur. (7, 9-12)

Tanıda en önemli inceleme metodu bilgisayarlı beyin tomografisidir. Intrakranial kalsifikasyonlar globus pallidus başta olmak üzere s1klıkla putamen, kaudat nükleus, internal kapsül, dentat nükleus, talamus ve serebellumda görülürler. Kalsifikasyonların en önemli özelliği simetrik olmasıdır $(13,14)$.

Klinik bulgular oldukça değişken olmas1na rağmen nöropsikiyatrik, ektrapiramidal ve serebellar semptomlar sıklıkla izlenir. Kişilik değişiklikleri, konuşma bozuklukları, mental ve zihinsel işlevlerde bozulma, demans ve duygulanım bozuklukları gibi davranışsal bozuklukların yanı sıra rijidite, hipokinezi, tremor ve ataksi gibi hareket bozuklukları da görülebilir $(15,16)$. Fahr sendromu bazal gangliyonları tuttuğu için bu vakalarda hareket bozuklukları görlebiliyor,ancak bizim vakamızda hareket bozukluğu yoktu,sadece baş ağrisı vard1.

$\mathrm{Bu}$ geniş ve gürültülü klinik spektruma rağmen, literatürde sadece baş ağrısı olan hastalar da bildirilmiştir. Baş ağrısı özellikleri geniş klinik spektrum göstermektedir. Bu olgu da polikliniğe baş ağrısı yakınmasıyla başvurmuştu ve nörolojik muayenesi normaldi. . Hipokalse-mi periyodu sirasinda serebrospinal siv1 emilimi an-laml olarak azalmaktadır. Ekstrasellüler ortamdaki kalsiyum azalması-nın hücre içinden sodyum akım oranını azalttığ1 gösterilmiştir. Aroknoit villuslardaki sodyum ve su artışı beyin

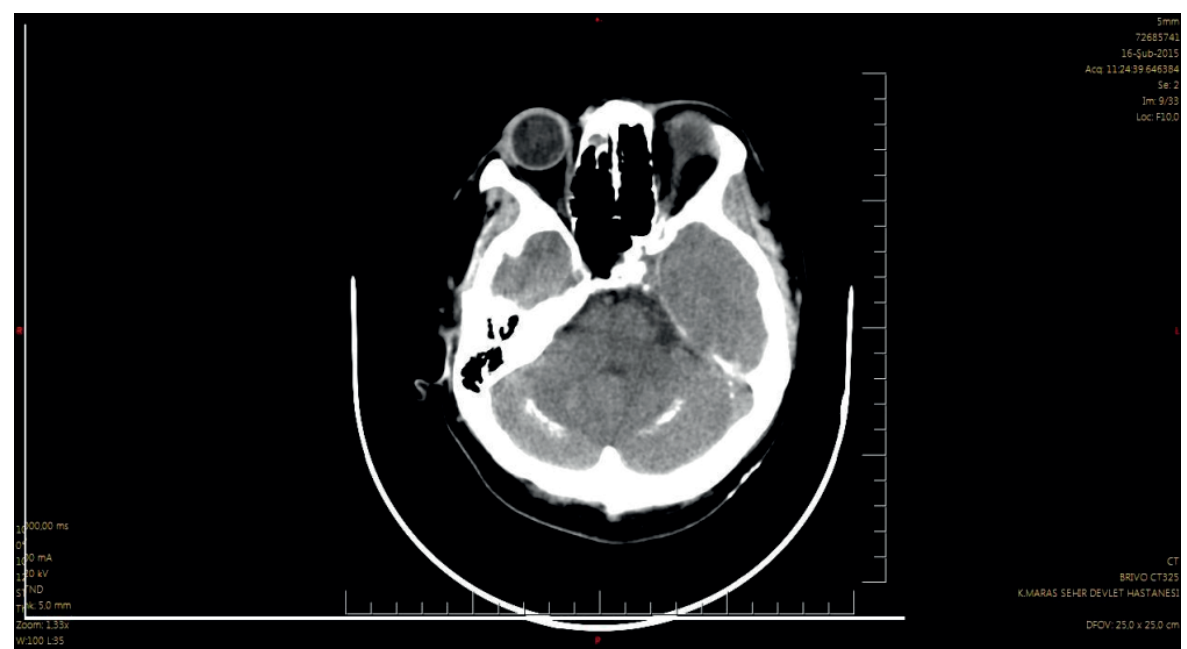

Şekil 1: Bilgisayarlı beyin tomografisinde bilateral serebellar kalsifikasyonlar

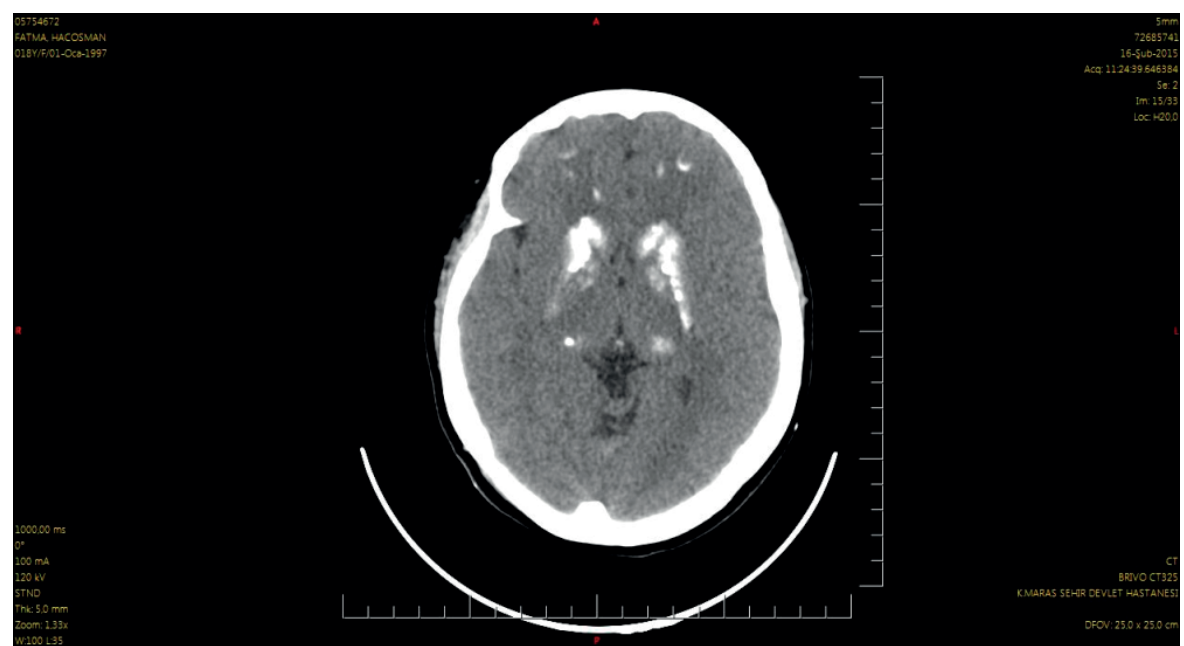

Şekil 2: Bilgisayarlı beyin tomografisinde frontalde, bazal gangliyonlarda ve talamusta kalsifikasyonlar

omurilik sıvısının araknoit villuslar tarafindan emilimini engellemektedir. Hipokalse-minin düzeltilmesi ile beyin omurilik sıvısının emi-liminin normale döndüğü gösterilmiştir $(12,17,18)$.

Fahr Sendromunun; intrakranial kalsifikasyonun sebep olduğu geniş bir klinik spektrumu vardır. Baş ağrısı bu klinik spektrumun erken safhasıdır. Fahr sendromlu vakaları erken dönemde saptayabilirsek, belki de uygun hipokalsemi tedavisiyle hastalığın ilerlemesini önleyebiliriz. Baş ağrısına eşlik eden semptomlara dikkat etmeli; hasta, özellikle hipokalsemi semptomları tarifliyorsa Fahr sendromunu aklımıza getirmeliyiz. 


\section{KAYNAKLAR}

1. Fahr T. Von. Idiopathische verkalkung der hirngefasse. Zentrabl. Allg. Pathol, 1930; 50:129-133.

2. Kobari M, Nogawa S. Familial idiopathic brain calcifications with autosomal dominant inheritance. Neurology, 1997; 48:645-649.

3. Scotti G, Scialfa G. MR imaging in Fahr disease. J Comput Assist Tomogr 1985; 9:790-792.

4. Windect $\mathrm{R}$, Menken U. Basal ganglia calcification in pseudohypoparathyroidism type II. Clin Endocrinol 1981; 15:57-639.

5. Beall SS, Patent BM. Abnormal systemic metabolism of iron, porphyrin and calcium in Fahr"s syndrome. Ann Neurol 1989; 26:569-575.

6. Esen R, Soyoral Y. U, Bora A. ve ark. Fahr Sendromu; İki Olgu Sunumu. Van Tip Dergisi, 2010; 17: 96-99.

7. Manyam B. V, "What is and what is not 'Fahr's disease' ", Parkinsonism and Related Disorders, 2005; 11: 73-80.
8. Tuglu D, Yuvanç E, Bal F. ve ark. Fahr Syndrome Unknown Complication: Overactive Bladder. Case Reports in Urology, 2014, Article ID 939268, 1-2.

9. Shakibai SV, Johnson JP, Bourgeois JA. Paranoid delusions and cognitive impairment suggesting Fahr's disease. Psychosomatics 2005;46:569-572.

10. Lazăr M, Ion DA, Streinu- Cercel A, Badarau Al. Fahr's syndrome: diagnosis issues in patients with unknown family history of disease. Rom J Morphol Embryo 2009;50:425-428.

11. Yürekli A. V, Gündoğar D, Özcankaya R, Koyuncuoğlu HR, Kutluhan S. Nadir bir demans sebebi: fahr hastalığı. S.D.Ü. Tip Fak. Derg 2007;14:32-34.

12. Koç E, Tunç S. Atipik klinik bulgular ile seyreden Fahr hastalığı: İki olgu sunumu. Klinik ve D S. eneysel Araştırmalar Dergisi 2010; 1

13. Avrahami E, Cohn DF, Feibel M, Tadmor R. MRI demonstration and CT correlation of the brain in patients with idio- pathic intracerebral calcification. J Neurol 1994;241:381-384.

14. Kaçar E. Nadir Görülen Bir İntrakranial Kalsifikasyon Olgusu: FAHR Sendromu. The Medical Journal of Kocatepe 2010;11: 31-33.

15. Cartier L, Passig C, Gormaz A, Lopez J. Neurophysiologycal and Neurophysiologycal features of Fahr's Disease. Rev Med Chil 2002; 130: 1383-1390.

16. Baydar C, Güneş H N, Yoldaş T K, Yılmaz A. Gerilim Tipi Baş Ağrısı ve Fahr Hastalığı Birlikteliği: Ankara Med J 2014; 14: 68-70.

17. Uslu FI, Hanağası HA. Hipoparatroidizm ve bilateral striopallidodentat kalsinozis. Nöropsikiyatri Arşivi 2006;43:31-36

18. Sambrook MA, Hill LF. Cerebrospinal fluid absorption in primary hypoparathyroidism. J Neurol Neurosurg Psychiatry 1977;40:1015-7. 
